\title{
Ottawa and Brisbane: Comparing a Mature Busway System with Its State-of-the-Art Progeny
}

\author{
Sean Rathwell and Stephen Schijns \\ McCormick Rankin Corp.
}

\begin{abstract}
Brisbane, Australia's new South East Busway, which opened in 2000-2001, is one of the most technologically-advanced Bus Rapid Transit (BRT) systems in the world. It represents the "state-of-the-art" in busway design, infrastructure, and operations management.

The South East Busway and various other Brisbane busway initiatives are modeled on Ottawa, Canada's transitway system. Since commencement of operation in the early 1980s, Ottawa's network of bus-only roadways and stations has transformed the community into one of the most transit-friendly centers in North America.

\section{Introduction}

This article compares the BRT systems operating in Brisbane and Ottawa. Some elements are similar between the two while other elements are fundamentally different. The article also shows how BRT proponents created a successful system while addressing real-world issues faced in various situations.

The comparison directly incorporates components of BRT that are outlined in the recent TRB/TCRP publication "BRT-Why More Communities Are Choosing Bus Rapid Transit." Thus, the reader can review the key elements of the successful Ottawa and Brisbane facilities in a systematic manner.
\end{abstract}




\section{Setting}

Ottawa, Canada's national capital, was founded in the 1820s on the south bank of the Ottawa River; Gatineau, Quebec, lies opposite the City. Ottawa spreads over flat, open terrain. Its 715,000 urban population has grown at a varying rate of between 1 percent and 2 percent per year over the past decade. The temperate climate sees daily average high temperatures of $-6^{\circ} \mathrm{C}$ in January and $27^{\circ} \mathrm{C}$ in July. The full range is $-37^{\circ} \mathrm{C}$ to $+38^{\circ} \mathrm{C}$. Snow is a major factor, with an average of $220 \mathrm{~cm}$ falling between November and April.

Ottawa relies on buses. The City's once-extensive streetcar system was closed in 1959. In October 2001, a five-station Diesel Multiple Unit (DMU) Rail pilot project was opened. The transit mode share is 16 percent of all daily trips, amounting to 80 million trips per year.

Brisbane, the capital of Queensland, was founded in the 1820s along the serpentine Brisbane River. The City is $10 \mathrm{~km}$ inland from Moreton Bay on Australia's east coast. The terrain is a mixture of flats and rugged forested hills. Brisbane's current population of approximately 880,000 (region 1.6 million) has grown at a rate of 2 percent per year over the past decade. The climate is subtropical, with January daily high temperatures averaging $29^{\circ} \mathrm{C}$ and July averaging $20^{\circ} \mathrm{C}$. The full annual range is $2^{\circ} \mathrm{C}$ to $43^{\circ} \mathrm{C}$. Brisbane receives $120 \mathrm{~cm}$ of rain per year but has never experienced snow.

Brisbane has an extensive commuter rail network, splitting the transit market almost equally with the bus system at around 42 million trips per year. River ferries are also part of the transit mix. The City's once-extensive streetcar system was closed in 1969. There are several on-street bus lanes, high-occupancy vehicle (HOV) lanes, and priority measures in place. A freeway HOV lane was built adjacent to the South East Busway as part of the corridor works. Transit mode share is 7 percent of all daily trips.

\section{Rationale and Concept Development}

The region of Ottawa-Carleton was created through amalgamation in 1969 and set out to prepare an Official Plan (OP). The key OP statement was to "give precedence to public transit over all forms of road construction or road widenings" (Regional Municipality of Ottawa-Carleton 1974). The OP also linked land 
use and transportation by placing most major employment centers next to rapid transit facilities. With provincial funding of 75 percent of transit infrastructure capital costs, the scene was set for developing a rapid transit strategy. The study of modes, costs, and service recommended transitways (grade separated) in five corridors. A detailed study of need, location, priority, staging, and technology followed in 1977-1981 (BBL-DeLeuw Cather-Dillon-IBI Group 1976). Diesel buses were selected over light rail transit (LRT) for reasons of cost and flexibility. BRT was seen as half as costly to build as LRT and 20 percent cheaper to operate, while providing a high proportion of transfer-free trips.

In the face of continued substantial growth in the 1980s and 1990s, Brisbane City Council and Queensland Transport collaborated on an Integrated Regional Transport Plan (IRTP) (Queensland Transport 1997) in the mid-1990s. Senior Brisbane staff and politicians had been impressed with the Ottawa approach to bus-based rapid transit and came up with a busway strategy for Brisbane (McCormick Rankin 1995), which was incorporated in the IRTP. Corridor studies followed as part of the IRTP process. In the southeast corridor, the government was quick to take advantage when a controversial proposal for a new highway to the Gold Coast was rejected in favor of widening the existing route. The State's commitment to upgrade the freeway through the urban area was met in the form of two bus lanes (i.e., busway). Under that rationale, the State government funded and built the South East Busway, while planning continues in the other corridors.

\section{Route Planning}

The Rapid Transit Appraisal Study identified five corridors radiating from central Ottawa (BBL-DeLeuw Cather-Dillon-IBI Group 1976). The corridor across the river to Quebec fell afoul of complicated planning, jurisdictional, and funding matters. In the other four, route selection reflected environmental, community, transit service, and cost factors (BBL-DeLeuw Cather-Dillon-IBI Group 1978-1981). Community and public input was substantial. The routes mainly used publicly owned land such as old streetcar rights-of-way, surplus freeway land, and parkway belts. They linked most of the major trip generators (employment, retail, service centers) in the region. An "outside in" strategy was used, 
concentrating on construction in suburban corridors while operating on-street in bus lanes through the central business district (CBD), deferring the cost and impact of a CBD bus tunnel.

A Busway Strategy for Brisbane City (McCormick Rankin 1995) also identified five potential BRT corridors reflecting Brisbane's radial bus service pattern, but available rights-of-way were much more constrained than in Ottawa. With six radial rail routes already in place, the bus corridors avoided service area overlaps by locating between rail lines and providing intermodal transfer stations where technologies intersect. Within built-up corridors, a mix of grade-separated and on-street bus lane operations were contemplated in the concept plan, but most of the on-street segments in the South East corridor were replaced with tunnels during detail design, leading to a greater per-kilometer construction cost. The subsequent Inner Northern Busway makes more extensive use of existing roads.

Brisbane's preexisting underground CBD bus station provided a logical meeting point for the busway network. In time, the City intends to convert this terminal to an on-line station busway. Like Ottawa, getting the busways to the CBD was a higher priority than undertaking the costly link through the CBD itself.

\section{Infrastructure Planning and Design}

When Ottawa embarked on its busway initiative in the late 1970s, there were few reference materials or working examples available, and none featuring a northern climate. The Transitway Design Manual (Regional Municipality of Ottawa-Carleton 1993) was created from principles, covering all necessary structural, architectural, electrical, drainage, station layout, and geometric elements. Without operating experience, standards tended to be conservative with respect to such items as the need for shoulders and acceleration lanes. Where information was lacking, local field trials were arranged (e.g., bus acceleration out of stations, passenger reaction to platoon operation, station capacity under full operation). Considerable debate took place over station operations and platform length. Although bus had been selected over light rail to begin with, it was decided to project for LRT where it was cost-effective to do so. Thus, structural design, 
Ottawa and Brisbane

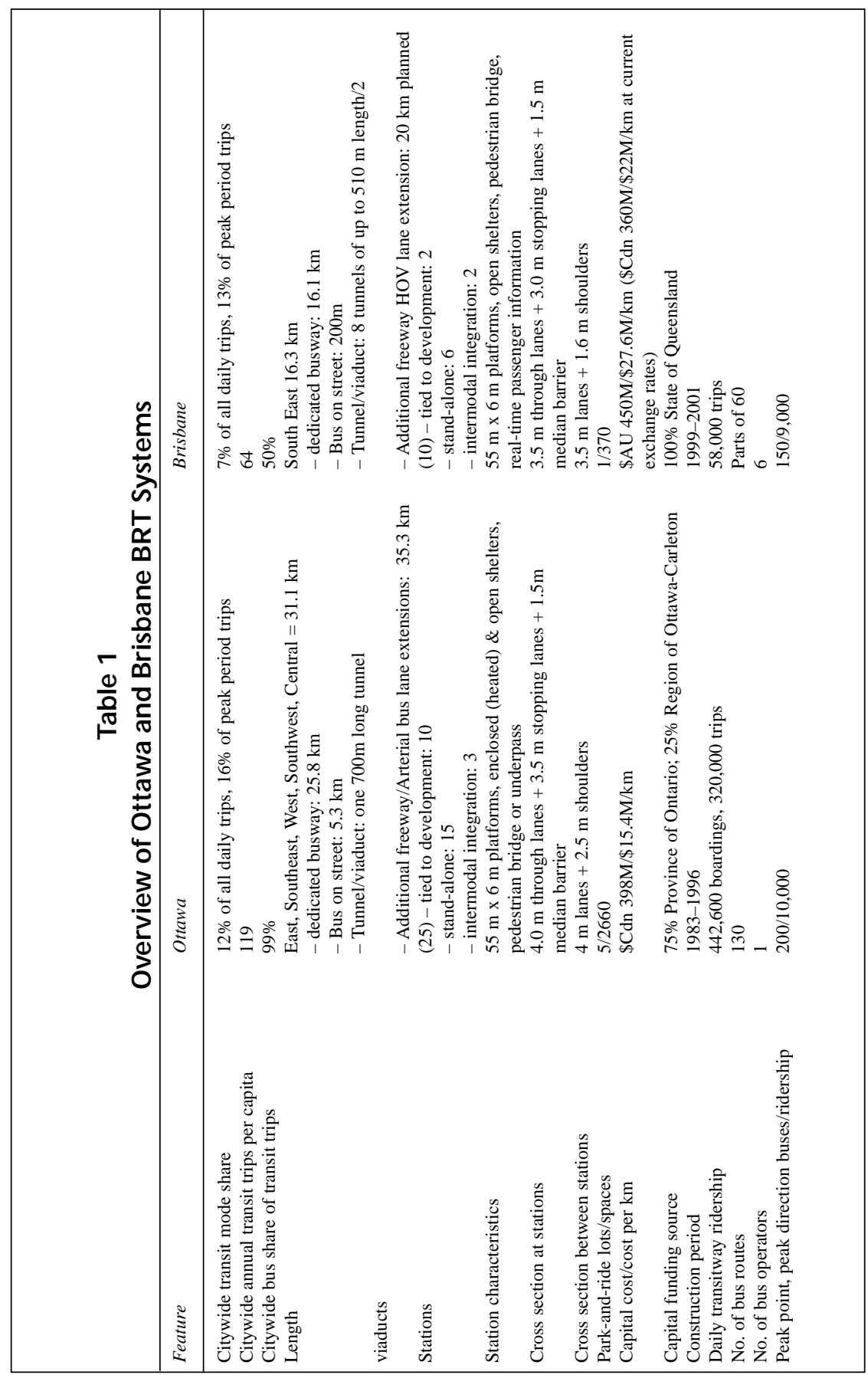


clearances, and grades used LRT criteria. Perhaps the wisest decision was to treat the stations as significant, substantial "places" rather than as glorified bus stops; enclosed walkways and heated shelters meant that to transfer between buses in February no longer risked being a bitter, uncomfortable ordeal.

The Ottawa model of establishing as much as possible in a design manual before soil was turned was followed in Brisbane (McCormick Rankin International 1998). And, as experienced in Ottawa, the concept was new to Queensland and much had to be adapted from roadway experience. An architectural approach specific to Brisbane was developed, much more open than the winter-guided Ottawa style. Brisbane had longer and more numerous tunnels and more complex bus operations than Ottawa. Planners took advantage of latter-day advances in Intelligent Transportation Systems (ITS) technology to create a "wired busway" from the start. Colocation with light rail was a serious prospect in Brisbane at the time, with the Ottawa approach taken to protecting for LRT needs.

\section{Running Ways-Standard}

Ottawa's basic transitway is nothing more than a two-lane roadway with paved shoulders. The travel lanes, at $4.0 \mathrm{~m}$ wide, are wider than typical general traffic lanes to provide an extra safety margin and reduce the air pressure disturbance between buses passing at $80 \mathrm{~km} / \mathrm{h}$. Vertical alignment, structural design, and clearance envelopes are governed by LRT constraints to protect for possible future conversion.

Paved shoulders were included as a refuge for disabled buses and for snow storage. Experience has shown, however, that if buses break down, they do so at stations so shoulders are rarely used for that purpose. The primary function of the shoulders is, therefore, for snow storage though they also do provide operational flexibility during road maintenance. In constrained areas, gutter drainage and mountable curbs are used. Shoulders are $2.5 \mathrm{~m}$ wide.

At stations, the road widens to four lanes to allow express buses to pass stopped ones at $50 \mathrm{~km} / \mathrm{h}$.

The design approach used in Ottawa was followed in Brisbane, with the obvious difference of not requiring shoulders for snow storage. The commitment 
to full grade separation from crossing roads was maintained wherever physically possible. The lane width in Brisbane is $3.5 \mathrm{~m}$, while shoulders are $1.6 \mathrm{~m}$ wide.

Learning from Ottawa's experience, bus deceleration and acceleration lanes at stations are trimmed to $20 \mathrm{~m}$ in length. It has turned out that the full length lanes provided in Ottawa (in the absence of operating experience, based on highway standards) were not used in real operating conditions; relatively low traffic volumes mean buses can reenter the through lane from a station with ease.

\section{Running Ways - Exceptions}

Key to transit's success and cost-effectiveness in Ottawa was the initial development of a region-wide BRT service that made selective use of existing roads, on-street bus lanes, and freeway bus ramp-stations. Although every year or two after 1983 new sections of busway were added, replacing temporary street and busway operations, the overall BRT service has remained essentially unchanged. Today, freeway shoulder bus lanes extend the transitway to suburban communities, while arterial bus lanes extend the system to the south. Eventually, these, too, will be replaced by busway. Through the downtown, on-street bus lanes link the East and West transitways. They operate in the second lane on a pair of one-way streets, leaving the curb lane for bus stops, couriers, right turns, and parking. A central tunnel was originally planned but was deferred to allow the rest of the transitway to be built first. This "outside in" strategy was the key to being able to afford an extensive transitway system in the first place. The success of on-street bus lanes means the costly tunnel is unlikely to ever be built.

The $25.8 \mathrm{~km}$ of transitway built between 1983 and 1996 cost \$Cdn 398M (approximately US $\$ 250 \mathrm{M}$ at current exchange rates), or $\$ \mathrm{Cdn} 15.5 \mathrm{M}$ per km, including 25 stations.

The extensive tunnel and viaduct segments of Brisbane's South East Busway maintain lane and shoulder width standards. The four-lane Victoria Bridge into the CBD was changed to carry the two-way busway alongside a twoway general-purpose roadway. At the busway's south end, buses transition to the Pacific Motorway, where they will eventually be able to take advantage of planned median HOV lanes to serve strategic stand-alone stations. The $16.3 \mathrm{~km}$ 
of busway and 10 stations built in 1999 to 2001 had a total capital cost of approximately \$AU 450M (approximately US \$230M at current exchange rates), or \$AU 27.6 M per $\mathrm{km}$.

\section{Station Design}

Transitway stations in Ottawa are substantial, distinct facilities, heavily influenced by the winter weather (Figure 1). A modular "kit of parts" was defined and applied across the system, for stronger "branding" and economy of scale. The bright red steel frames, curved glass, and concrete bases were far more substantial than bus passengers had been used to and signified that their comfort was being taken seriously for a change. Heated, enclosed on-platform waiting areas provide winter relief as well as central locations for passenger information. All stations are four lanes wide to allow express buses to pass stopped ones. Drainage is toward the median to eliminate the risk of waiting passengers being splashed. A barrier/fence in the median prevents pedestrians from crossing the transitway. Movement between platforms is by a bridge accessed by stair and elevator. Most platforms are $6 \mathrm{~m}$ wide x $55 \mathrm{~m}$ long.

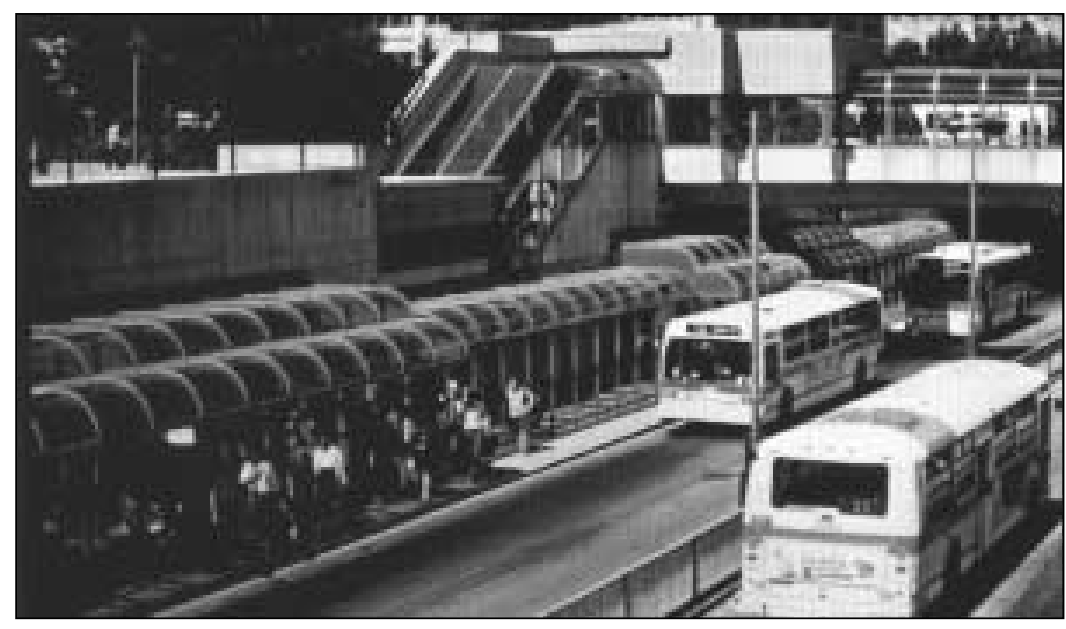

Figure 1. Tunney's Pasture Station, West Transitway, Ottawa

The general approach to stations in Brisbane followed Ottawa's lead-a substantial, distinct, identifiable, functional, modular architecture—but design 
focuses more on protection from subtropical sun and rain, with broad canopies over open platforms (Figure 2). The platforms are $6 \mathrm{~m}$ wide x $55 \mathrm{~m}$ long, using Ottawa's "lead stop" operational principle. Highly visible elevator towers linked by an enclosed pedestrian bridge mark most stations. The tropical green and horizontal elements help the stations blend in to their surroundings much more than in Ottawa. Each station precinct was subject to an urban design effort.

Like Ottawa, park-and-ride facilities were consciously limited to the outermost station. This represents a significant break from Brisbane's traditional reliance on park-and-ride provisions at rapid transit (i.e., rail) stations.

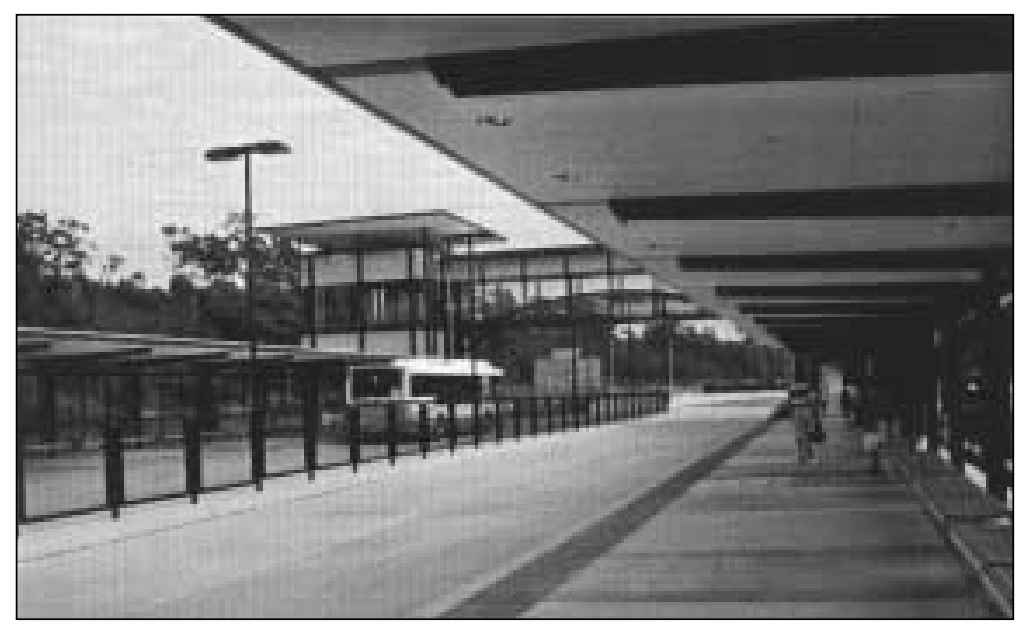

Figure 2. Griffith University Station, South Busway, Brisbane

\section{Station Integration}

Of Ottawa's 28 transitway stations, more than one quarter are physically integrated with adjacent development. The most significant example is at St. Laurent Shopping Centre, where the owners donated the land (in return for relief on parking requirements) and a bilevel station, linked directly to the mall, was created (Figure 3). Some 30 percent of St. Laurent patrons now come by bus. This formula was repeated at Blair, Orleans, Billings Bridge, and South Keys. At Riverside Hospital, an expansion reached out atop the new station (Figure 4). Most other stations are stand-alone with links to nearby attractions. 


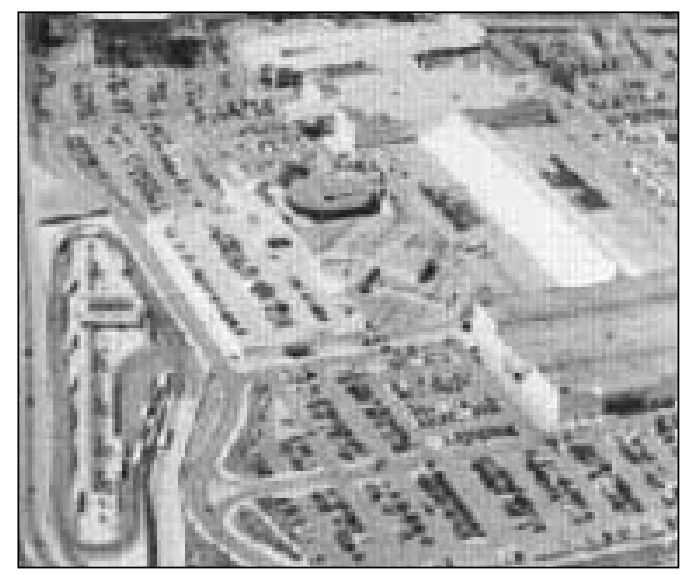

Figure 3. St. Laurent Station, East Transitway (lower left) linked with Regional Mall (surface level shown; transitway operates in tunnel below)

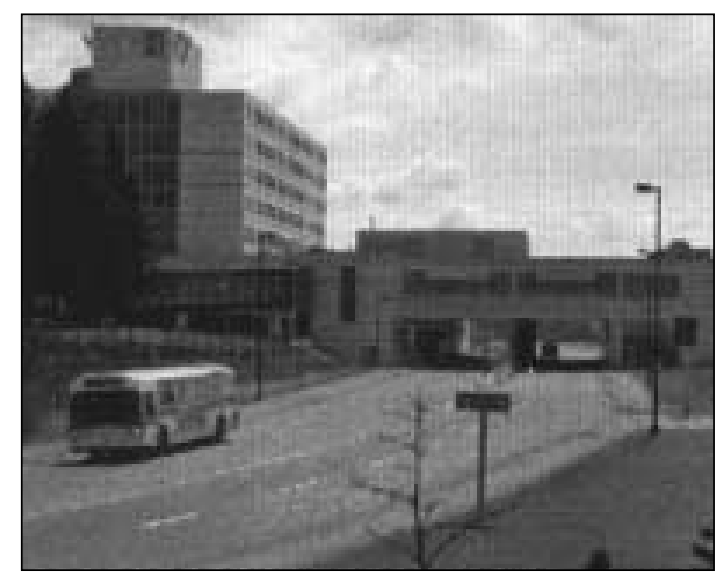

\section{Figure 4. Riverside Hospital extends over a transitway station}

The South East Busway has 10 stations. Like Ottawa, one station is integrated into a regional shopping center (Garden City) and the other is within a hospital complex (Mater Hill). In both cases, busway construction was tied into concurrent site redevelopment work. Although a complex legal and working environment ensued, the resulting coordinated facilities benefit both parties. At Mater Hospital, new operating theaters are suspended above the busway station (Figure 5). 


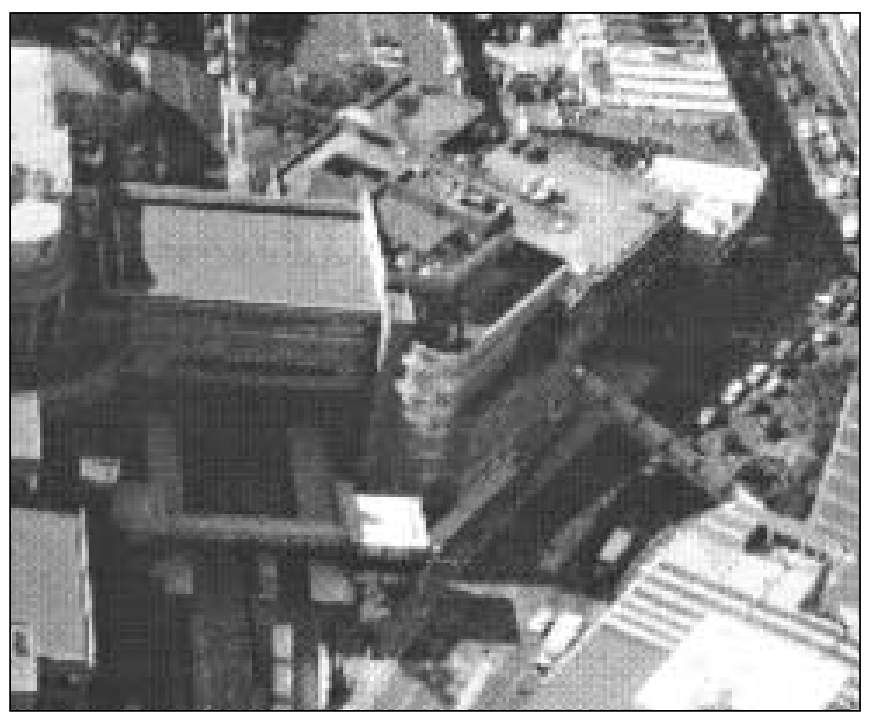

Figure 5. Mater Hospital straddles the busway and station

Two other stations provide direct links to adjacent commuter rail stations and have created significant new transfer opportunities.

The Cultural Centre station was the product of intense negotiations between the proponent and the stakeholders in an architecturally-controlled arts precinct. It was designed to provide for dual LRT and bus functions, but with the demise of the LRT proposal it is to be rebuilt to function better as a purely bus-oriented facility.

\section{Vehicles}

Ottawa does not apply special vehicles to the transitway. Standard 40-foot and articulated 60-foot diesel buses are used across the OC Transpo fleet and any route can be assigned any bus. The all-stops trunk transitway services are normally provided by articulated buses. Selected transitway buses carry bicycle racks. OC Transpo has investigated the use of natural gas but determined that the costs of mid-day fueling and retrofitting indoor storage (a requirement given the winter conditions) for the 800-plus fleet are prohibitive. OC Transpo is acquiring improved diesel technology as new buses are purchased and is observing fuel cell tests with interest. Use of the underground station at St. Laurent by diesel 
buses has not been an issue. The station features open platforms and its ventilation system was designed for such uses.

Brisbane's South East Busway is used by several operators, although the vast majority (approximately 80\%) of the buses are part of the City-owned Brisbane Transport (BT) fleet. BT, like OC Transpo, has a fleet of standard and articulated diesel-powered vehicles, although there are only 22 artics in use at present. Many of the other operators serve long-distance (20-30 km) suburban areas and use single-door highway coaches. Most buses use the underground Queen Street bus station in central Brisbane. Platforms there are enclosed to prevent migration of emissions to the adjoining retail areas.

All bus operators undergo a training course before being authorized to use the busway.

\section{Route Structure}

Four types of service operate on Ottawa's transitway system: mainline, crosstown, local, and peak period. Articulated buses stopping at all stations provide main line service at a frequency of 3 to 5 minutes in the peak and 5 to 8 minutes at other times. Some crosstown routes simply use the transitway to connect two areas of the City, while local routes feed stations and connect neighborhoods. Peak-period expresses are the highlight of Ottawa's BRT system, circulating within suburbs then running express via the transitway with time and reliability results the automobile can not beat. Some reverse expresses serve outlying centers in peaks periods. Almost all of Ottawa's 130 bus routes use or touch a segment of the transitway. Combined services result in one bus per minute in outlying areas and more than 200 buses per hour per direction in the CBD.

Brisbane's established pattern of suburb-to-CBD express services was supplemented by new busway trunk (all-stop) runs to accommodate transit demand. Trunk service now operates at 2.5-minute headways in the peaks. The frequent trunk busway service will allow development of new neighborhood feeder services. Unlike Ottawa, Brisbane's busway accommodates several different operators. Suburban contractors stop at one or two outlying stations then run express to the $\mathrm{CBD}$, while BT picks up everything in between. Express passengers can transfer to the frequent all-stops services to gain access to intermediate stations. 
New service agreements reflect the impact of the busway on suburban operators, allowing operators to pick up passengers within each others' areas. The South East Busway hosts parts of some 60 bus routes, with 150 buses per hour per direction during peak periods.

\section{Fare Collection}

Ottawa chose to continue using the conventional on-bus fare collection technology and fare media applied to the rest of the system. This allowed stations to be unstaffed; there are no fare-paid areas on platforms. The associated risk of lengthy boarding times was mitigated by the promotion and high uptake of monthly passes (some $70 \%$ of OC Transpo trips use monthly passes; higher during peak commute times) and by allowing rear-door boarding of articulated buses by pass users and passengers with proof of payment (a transfer from another bus). A random inspection program minimizes fraud. Cash fares are significantly higher than pass users, and express buses command a premium fare. OC Transpo plans to move to a Smart Card fare system in the future.

The fare system in Brisbane is considerably different from Ottawa's. BT features a zone-based fare system and bus drivers make change on the vehicle. The system does not offer monthly passes. Given these conditions, along with single-door entry and relatively few articulated buses in use, the risk of delays at stations with heavy boarding volumes is a major planning concern. The situation has been manageable to date. For special events, on-platform ticket agents are used to speed boarding, and the substantial use of one-seat express trips has reduced transfers at stations. However, the busway project has been a catalyst for Queensland Transport to introduce a Smart Card program, which will improve station operations and allow improved coordination between bus operators and between bus and train services. The Smart Card program was not in place for busway opening but is anticipated in the next year or two.

\section{Intelligent Transportation Systems (ITS)}

Ottawa's transitway system predates much of what is currently known as ITS, although OC Transpo has always been in the forefront of automated vehicle location and control (AVLC), passenger information (automated next bus 
information by phone), and automatic passenger counting. AVLC "electronic signposts" provide bus location information to service control center operators, who look after the entire system and can consider the network implications of any service interventions. Stations have push-button help phones, and cameras are gradually being introduced to ensure customer security. The transitway is not treated separately from the rest of the OC Transpo system.

The Queensland government made ITS an integral part of the busway project from the start. Bus operational management, plant (tunnel systems, elevators, pumps, etc.) monitoring and control, passenger security, and passenger information were all addressed with state-of-the-art technologies applied in each area. Brisbane City Council's RAPID bus monitoring system (tracking tagged buses via in-road detector loops) was extended to the South East Busway and used as a basis for real-time dynamic "next bus" information provided to passengers at stations. Since neither the Brisbane traffic control center, the highway traffic operations center, nor the BT radio room were physically or operationally capable of taking on the new busway task, all systems were brought together at a purpose-built busway operations center (BOC). Rather than have each operator run its own buses on the facility, the need for coordination and safety means that bus management is "handed off" to the BOC from the operators' own dispatchers upon approaching the busway. ITS features help protect the State's infrastructure investment while meeting traveler expectations and attracting new transit users.

\section{Organizational Structure}

The Region of Ottawa-Carleton (now City of Ottawa) built the transitway, with 75 percent of the capital cost provided by the Province of Ontario. The City is also responsible for OC Transpo, the monopoly transit service in Ottawa. OC Transpo adapted its organizational functions to reflect its responsibility for operating the new facility. Plant Maintenance took on the maintenance task, Operations shifted to focus on major transitway stations, new passenger security activities were implemented, and Public Information adapted to the new system.

The State of Queensland built the South East Busway for use by area bus 
operators. The State contracts out bus operations on a geographic basis and is not itself a service provider. One of the greatest challenges, therefore, in operating Brisbane's first busway was to define an appropriate organizational structure. Queensland, having funded its construction, could not simply hand the $\$ 500 \mathrm{M}$ facility to Brisbane City, nor did the City want to take on the maintenance and operating cost of the facility. The State's Public Transport division mainly managed contracts and had little tradition of owning or operating major infrastructure, while local bus operators had neither the interest in taking it on nor the resources to do so. Although the busway lies entirely within the BT service area and it is the major user, other suburban operators that use it to serve the vital CBD market did not wish to yield control of their operations on the busway to BT. Consideration was given to privatizing the facility and/or its operation.

The solution was to operate the facility initially under State direction, while working toward a permanent administrative structure that may or may not involve the City, bus operators, and/or the private sector.

\section{Performance and Ridership}

OC Transpo's ridership peaked at 85 million annual riders in 1985, shortly after the first sections of the transitway opened. Subsequent large-scale changes (growth in suburban office parks, downsizing by the City's major employer [federal government], and a sociodemographic swing away from the prime transit market) saw ridership drop to 70 million by 1998. During this period, transitway use remained stable. Increased population, economic growth, and service restructuring have since seen ridership rebound to almost 85 million per year. Weekday systemwide boardings are currently 442,600, of which 200,000 are on the 68 bus routes assigned to trunk transitway services. The peak-period peakpoint load on the transitway exceeds 10,000 passengers per direction.

BT carries approximately 42 million trips per year and recent years have shown a moderate growth trend. In the first week of operation on the South East Busway, BT reported an increase of 25.7 percent in patronage on core busway services. The increase was 40 percent after six months and has continued to grow, albeit at a more moderate pace. Some 58,000 trips per day are currently being taken on the busway. The one park-and-ride lot is full. 
The impact on ridership of improved bus travel time and reliability compared to operating in congested freeway and street traffic was difficult to model because of the lack of comparable local experience. Consequently, demand modeling underestimated patronage take-up. The 10-minute frequency of the allstops spine service was quickly reduced to 2.5 minutes in peaks and 5 minutes off-peak-above the year 2011 targets. The main problem in the first year of use was overloading and lack of buses to keep up with demand. The A.M. inbound peak-hour, peak-point volume on the South East Busway is 150 buses carrying 9,000 passengers.

\section{Impact}

The transitway has been one of the key components of making public transit an important part of everyday life in Ottawa. The integration of stations with adjacent land use and the provision of innovative services to take advantage of the facility has meant that:

- more than 50 percent of all people entering downtown do so by bus;

- the suburban St. Laurent Shopping Centre features a remarkable 30 percent transit mode share for shoppers;

- 3,200 residential units and 440,000 $\mathrm{m}^{2}$ of institutional and commercial space was built near transitway stations in the eight years prior to 1996; and

- bus is the fastest mode available between the airport and downtown.

Brisbane's South East Busway was an immediate success in terms of operations and ridership. The first week of full operation saw BT record a 26 percent increase in core busway service use; after six months, the increase had reached 40 percent. Gains continued until all available buses were operating with standees; further promotion has been held in abeyance pending acquisition of additional buses. Passengers are changing long-held travel patterns to use the new transfer and stopping opportunities. The system carries up to 60 percent of the crowd to sports events at Woolloongabba Stadium, Brisbane's major venue, up from 10 percent prebusway. 
Busway extensions and further service improvements yet to come will continue to draw new travelers to this mode. The impact of the busway on its surroundings has yet to be strongly felt, apart from those stations that were integrated into existing development. Nevertheless, some sites do have (re)development potential. An analysis of property values eight months after the busway opened showed that values in residential neighborhoods served by the South East Busway had grown at a rate up to two to three times faster than in nonbusway suburbs.

\section{Challenges}

Ottawa's transitway benefited from provincial funding; without the 75 percent contribution to capital cost from Ontario it never would have been built. The elimination of that support in the late 1990s, and the recent reinstatement of partial support, has posed problems for the completion of planned extensions. In the meantime, despite Ottawa being one of the touchstones of bus-based rapid transit and the busway being highly rated by its users, political interest has swung toward LRT. An $8 \mathrm{~km}$-long diesel LRT pilot project opened in 2001, utilizing a little-used freight line to link two transitway stations with three intermediate stops; its current daily ridership is about 4,500. Future LRT initiatives may be more challenging, however. The on-street bus operation through downtown would undeniably be better via a tunnel, but the incremental benefit may not be worth the price. Despite the strength of Ottawa's commitment to transit planning principles, the inability to control the location of development has meant that much recent growth has occurred in suburban areas far from the transitway or in sprawling non-transit-oriented "power centers."

Queensland's first busway is being carefully assessed to determine if it is a one-off product of a unique combination of political, financial, and functional circumstances or is a valid prototype for the rest of the proposed five-line network. Construction is underway on the $5 \mathrm{~km}$-long Inner Northern Busway, albeit on less generous financial terms. Other corridors may evolve through on-street bus priority measures instead. In any case, the State will have its hands full for years to come in sorting out an appropriate administrative structure; introducing regional Smart Card/fare integration measures; resolving the capacity and operational problems posed by the Cultural Centre, Queen Street bus terminal, and 


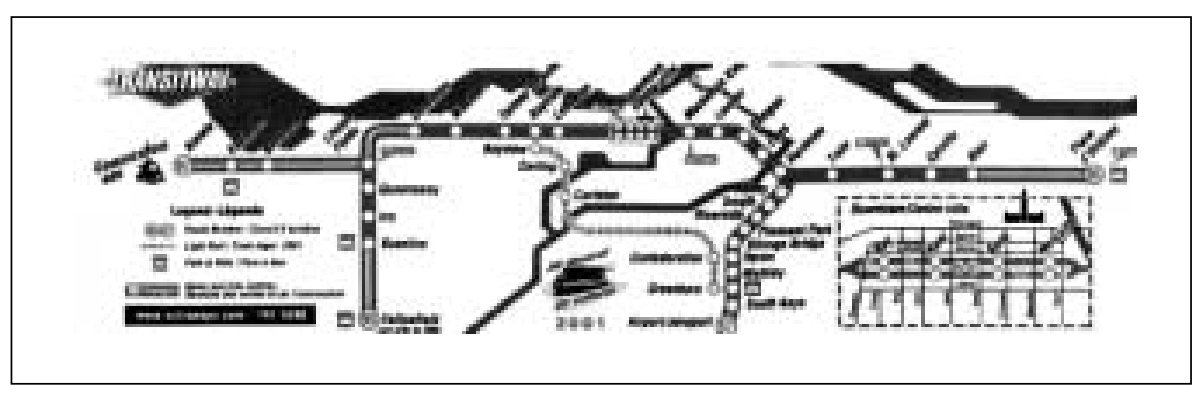

Figure 6. Ottawa transitway system

CBD street use; capitalizing on development opportunities around stations; and updating operator agreements.

\section{Conclusions}

Ottawa's transitway system was a success from the start and in its mature state provides the City with some of the best bus-based rapid transit in North America. Key has been the organizational structure that allowed a single public entity to plan, design, construct, operate, and maintain both the transitway system and all the vehicles on it. The transitway facilities and services are treated as integral, but not special, parts of the OC Transpo system (Figure 6).

Ongoing political commitment to an Official Plan that emphasizes transit before private automobile as well as the important land-use/transportation interaction has been evident in Ottawa since the early 1970s. This has allowed transit, in general, and rapid transit, in particular, to achieve a universal awareness in the community.

The transitway system incorporates on-street operation, freeway and arterial bus lanes, and signal priority to supplement the bus-only roadway backbone. This highlights the fact that the user's interaction with an effective BRT system is at stations; what lies between is only important insofar as it moves passengers between stations. The focus on stations-location, scale, amenity, and function-that is the hallmark of the transitway system has served it well.

Queensland had the opportunity to observe the world's best practice and learn from it. Within a very short period of time, Brisbane went from a place where the busway concept was unknown to operating a tremendously successful 
\$AU 450M facility. The level of funding and commitment to quality for the South East Busway may prove to be unsustainable, but it has set a high standard.

Over and above the busway's impact on individual travelers in the Brisbane area, its role as a catalyst for organizational and functional change cannot be understated. Unlike Ottawa, responsibility for public transport is split between State and City, a situation that in the past had proven difficult to overcome. The South East Transit Project broke the logjam.

In bus operations, infrastructure design, intermodal coordination, ITS, passenger service, and urban design, the busway moved far beyond established practice in South East Queensland and forced all those involved to raise standards, take new approaches, and work together in ways they never had before. The legacy will profoundly affect public transport in the State, while the busway and its future extensions will evolve into established elements of the region's transport system.

With only a year of full operation complete, it is too early to fully assess the impact of the South East Busway on the urban form and travel patterns of southern Brisbane. As the Inner Northern Busway comes on line and other corridors are developed for BRT, the impact of the transportation decisions made by Queensland in the 1990s will be felt for decades to come. Initial success in terms of operational functionality, public acceptance, and ridership bodes well for the BRT future in Brisbane. At the very least, Brisbane has demonstrated the transferability of the busway/BRT concept between different settings-and hemispheres.

\section{References}

BBL-DeLeuw Cather-Dillon-IBI Group. 1976. Rapid transit appraisal study. Ottawa.

BBL-DeLeuw Cather-Dillon-IBI Group. 1978-1981. Ottawa-Carleton rapid transit development programme, 1-8. Ottawa.

McCormick Rankin. 1995. A busway strategy for Brisbane City. Brisbane: Brisbane City Council.

McCormick Rankin International. 1998. Metropolitan Brisbane busway program-Busway planning and design manual. Brisbane: Brisbane City Council/Queensland Transport. 
Queensland Transport. 1997. Integrated regional transport plan for South East Queensland. Brisbane: Queensland Government.

Regional Municipality of Ottawa-Carleton. 1974. Official plan. Ottawa: RMOC.

Regional Municipality of Ottawa-Carleton. 1993. Transitway design manual. Ottawa: Transportation Department, RMOC.

\section{About the Authors}

SEAn Rathwell (srathwell@ mrc.ca)was involved in the planning, design, construction, and operation of Ottawa's transitway for 15 years. Mr. Rathwell holds bachelor and master of engineering degrees from Carleton University in Ottawa, Canada. He is a former manager of service planning at the OttawaCarleton Regional Transit Commission, and is currently a project manager with McCormick Rankin.

STEPHEN SchiJns (sschijns@ @mrc.ca.) has been directly involved in three of the milestone busway projects of the past two decades-Ottawa, Pittsburgh, and Brisbane. Mr. Schijns began his career as a designer on the Ottawa system and was stationed in Brisbane's South East Transit Project Office from 1999 until 2001. Mr. Schijns holds a bachelor of science degree from Queen's University, Kingston, Canada. He is a project manager with McCormick Rankin, where he has worked since 1983. 